\title{
A Review on SMAC: A New Dimension to the Business World
}

\author{
Kritika Singh \\ SRMS CET, \\ Bareilly
}

\author{
Shivang Goel \\ SRMS CET, \\ Bareilly
}

\author{
Ashish Agrawal \\ SRMS CET, \\ Bareilly
}

\begin{abstract}
As we are entering into the new business landscape, calling it "post digital era", our business world witnesses the emergence of new technology SMAC, that opens up ground for both customer and technology vendors. The indispensable technological trends social media, mobile technology, analytics and clouding (abbreviated as SMAC) join hands to bring in this Digital Transformation. Social media allows sharing and creation of knowledge easily accessible through Mobile technology which brings digital world on the fingertips of customer. The other two technology -Analytics and Cloud computing will help in allowing businesses to understand the customer's response and their buying behavior. The basic technologies compiled to produce this technology enables customer to increase their intellectual acuity and lead to new possibilities in business. In this paper we explore the potential and opportunity that will be produced by SMAC technology.
\end{abstract}

\section{General Terms}

Computing, Business Analytics

\section{Keywords}

Social Computing; Mobile; analytics; cloud computing; communication; growth

\section{INTRODUCTION}

In the last decade, various platforms an technologies are evolved that have shown a tremendous increment in the growth of industries. Under these platforms, Social, Mobile, analytics and Cloud platform are the base upon which various technologies built up to give a new edge to the technical field and to the way of using corporate data. These four names were evolved separately but now large corporate organizations have started calling and treating them as SMAC. This is the modern new generation ICT model that is willing to make professionals and customers more available, more connected, co-operative, impactful, in-touch, and quality oriented. In the current scenario, in terms of business productivity, the no. of computers is rapidly increasing and is on its way to 100 billion and data volume is mounting to around 35000 Exabyte which is more than 600 times the data under management at the end of the internet era before 2012 . The acronym "SMAC" was started in 2010 after a big growth in the fields of social networking, mobile computing, analytics and cloud computing. Table 1 shows the brief description of each of these technologies. These four platforms are well known and well used in their own clusters but now when they are integrated, they will surely lead to a more productive, customer oriented, quality oriented and business growth oriented corporate world. This paper is an attempt to dig out the growth of SMAC technologies, their meanings and their future aspects for corporate world.
Table 1. SMAC TERMS

\begin{tabular}{|l|l|}
\hline \multicolumn{1}{|c|}{ Term } & \multicolumn{1}{c|}{ Link with } \\
\hline Social & Get connected with involved person \\
\hline Mobile & Be closer and have knowledge at anywhere \\
\hline Analytics & Analyze process and results \\
\hline Cloud & $\begin{array}{l}\text { Where we performed the process and where we } \\
\text { store the results }\end{array}$ \\
\hline
\end{tabular}

\section{SMAC IN A GLANCE}

\subsection{S- Social Computing}

Social networking is a today's fast way of making relations, to meet older friends, to meet older friends, to advertise you. Social media is just not only a way of fun but also a way of new opportunities. From the development of social networking sites early in 1995, social media has seen a rapid growth in last decade. Face book, twitter, LinkedIn etc. are the best dishes on the platter called social networking. According to a survey published on sociallystacked.com,

- $72 \%$ of all internet users are now active on social media.

- $89 \%$ of $18-29$-year-old internet users are active on social media.

- $\quad 93 \%$ of marketers use social media for business.

- $\quad 70 \%$ of brands have a presence on Google+.

- Twitter is the fastest growing social network, up 44\% between June 2012 and March 2013. Google+ grew $33 \%$ during the same period.

- Face book has 1.15 billion monthly active users.

When face book was started in year 2004, it was started only with aim of making friends, having loved ones nearby and to find some lost friends. But now the scenario has a little bit changed, presently the face book is used for showcasing the talents, for increasing the business growth, for letting more and more people know about you and your success.

For professionals and Job Seekers, LinkedIn is like a panacea where one can find right job chance at right time at one and right place. With Twitter, everyone can share their views on social, cultural and political agendas with others in just one click.

\subsection{Mobile Computing}

Removing physical boundaries, making communication and knowledge sharing easier without the concern where you are. Here mobile means not just a device with which we are talking to someone, but it is more than talking to someone as mobile are now become smart phones with which a person can do almost anything that is possible with computers. 
Tablets, PDAs etc. are the other names of mobile devices that let the people available from everywhere. Characteristics of mobile devices include portability, size and wireless communication.

\subsection{Analytics}

Optimized utilization of all possible raw materials, data inference rules, UML models to provide a enlightened way for decision makers to improve their day to day functioning and analysis of milestone activities deeply. There are three main characteristics of Analytics:-Volume refers to quantity of data, Variety refers to divergent of the data and Velocity refers to the speed of data [2]. As we can feel as well as see that the current situation of education is at its lowest, we are not being able to produce good quality of engineers, doctors and other professionals. After seeing such a pathetic situation of education question arise why this situation has been occurring? And the answer is we are still using very old and conventional method of teaching, we emphasize more on the theory part than on practical as a result of which we are lagging behind some nation.

\subsection{Cloud Computing}

In last decade, up to 2007 grid computing was much in talk but after 2007 gradually cloud computing become point of discussion for every professional and up to 2012 it was right on top. In India, Hyderabad, Pune, and Bangalore are the top three cities in searching of cloud computing. Cloud computing is the model of shared network delivered services. According to Prof. R.K Buyya, cloud computing in market oriented distributed computing system consisting of a collection of interconnected and virtualized computers that are dynamically provisioned as presented as one or more unified computing resources based on Service Level Agreements establishment through negotiation between stakeholders. Cloud Computing may also be termed as elastic computing that shrinks and expands resources as needed automatically. The buildings of new innovations can be made upon the foundation of cloud computing. Table 2 shows the cloud services and their applications.

Table 2. Cloud Services

\begin{tabular}{|l|l|}
\hline $\begin{array}{c}\text { Cloud } \\
\text { Services }\end{array}$ & \multicolumn{1}{c|}{ Applications } \\
\hline IaaS & CPU, Storage, Amazon.com .... \\
\hline PaaS & $\begin{array}{l}\text { GoogleApp Engine, Manjrasoft Aneka Microsoft } \\
\text { Azure... }\end{array}$ \\
\hline SaaS & Salesforce.com......... \\
\hline
\end{tabular}

\section{REVIEW METHOD}

Before performing this review, we had built up some stages based framework which includes data collection, acceptance and rejection criteria, search strategy, quality assessment and data extraction.

\subsection{Data Sources and Data Collection}

The data searching strategy included online electronic data searches and manual searches of various national and international conference proceedings. In this context, following online journal's databases were searched-

- $\quad$ ASQ Digital Library

- IEEE Explore

- $\quad$ Springer Link

- Academia.edu

- Mobile company websites

- $\quad$ Science Direct-Elsevier

- $\quad$ Research Gate

Table 1: Terms for SMAC

\begin{tabular}{|c|c|l|}
\hline $\mathbf{S}$ & $\begin{array}{c}\text { Social } \\
\text { Technologies }\end{array}$ & $\begin{array}{l}\text { Facebook, Blogs, Twitter, E-Mail, Wikis, Instant Messengers and other social network } \\
\text { services and software applications that promote and assist interpersonal } \\
\text { communications, both business and personal }\end{array}$ \\
\hline $\mathbf{M}$ & $\begin{array}{c}\text { Mobile } \\
\text { Technologies }\end{array}$ & $\begin{array}{l}\text { Tablets, Smart phones, Personal digital assistants (PDAs), and global positioning } \\
\text { systems(GPS) to the network, applications and software which prop up and facilitate } \\
\text { robust anytime and anywhere connectivity }\end{array}$ \\
\hline $\mathbf{A}$ & $\begin{array}{c}\text { Analytics } \\
\text { Technologies }\end{array}$ & $\begin{array}{l}\text { These present new stages of empiricism and close by founding a software supply chain } \\
\text { of gathering, classifying, overseeing, determining, examining and reporting large } \\
\text { volume of dissimilar date on an fragmentary basis }\end{array}$ \\
\hline $\mathbf{C}$ & $\begin{array}{c}\text { Cloud } \\
\text { Computing } \\
\text { Technologies }\end{array}$ & $\begin{array}{l}\text { This set asides remotely based computing resources which includes applications, } \\
\text { database and servers to distributed via Internet instead of internal and permitting for } \\
\text { flexibility of resources with minimum cost }\end{array}$ \\
\hline
\end{tabular}




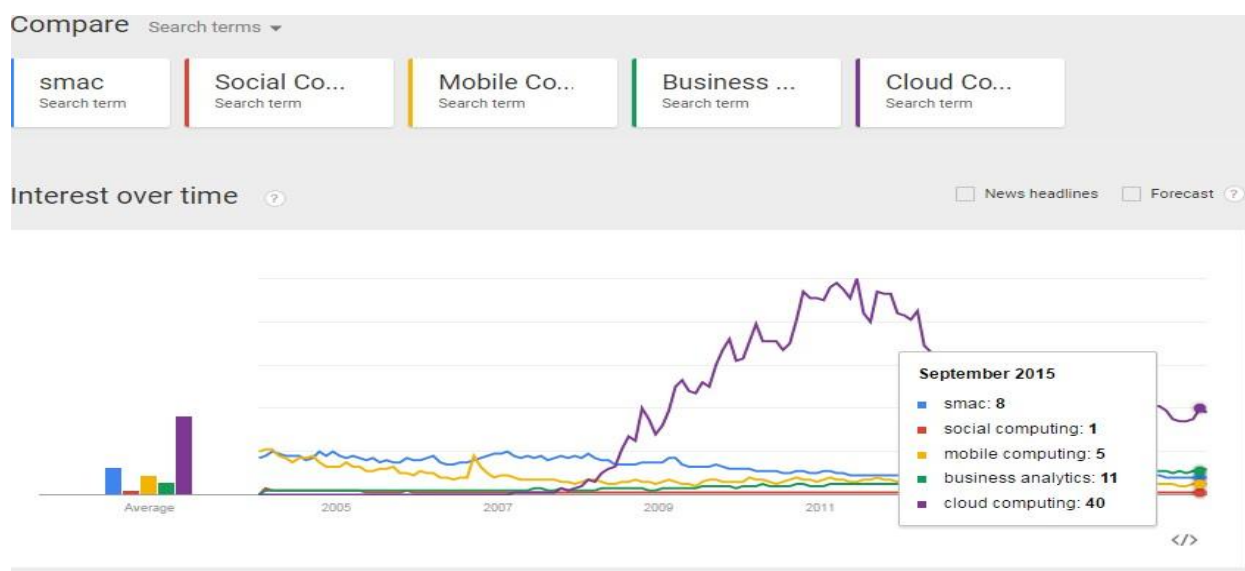

Fig 1 Comparison of Growth of SMAC computing in past years

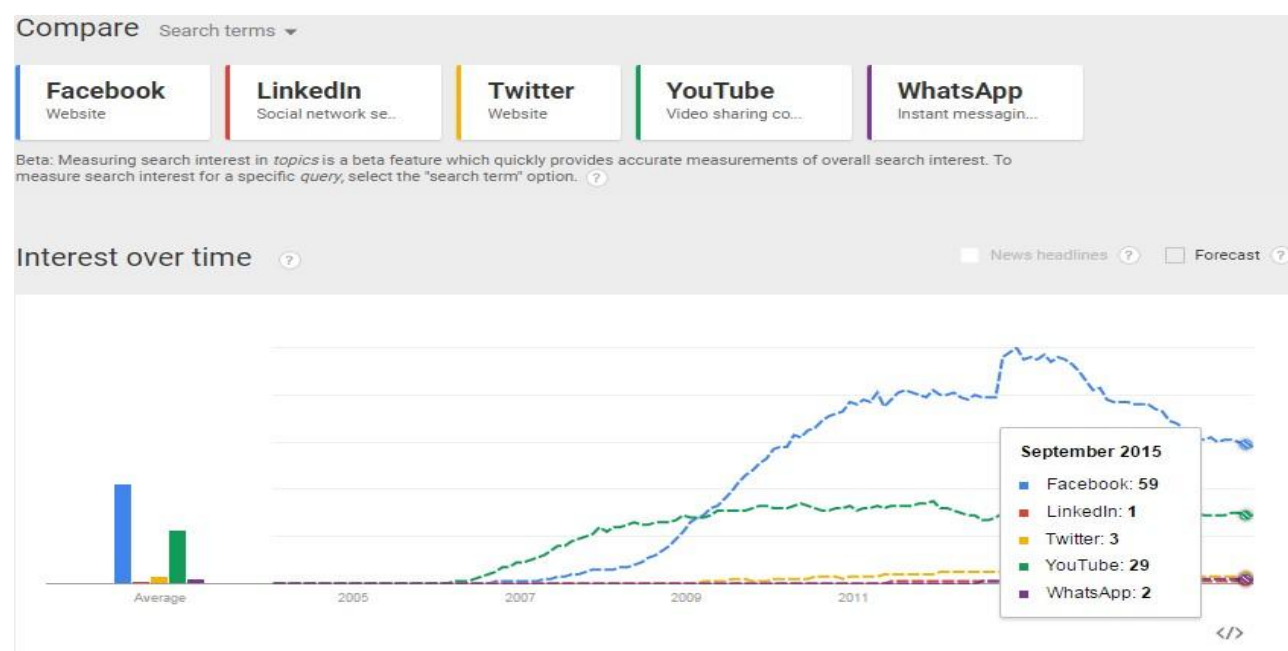

Fig 2 Comparison of Growth of various Social networking platforms in past years Jompare searchterms .

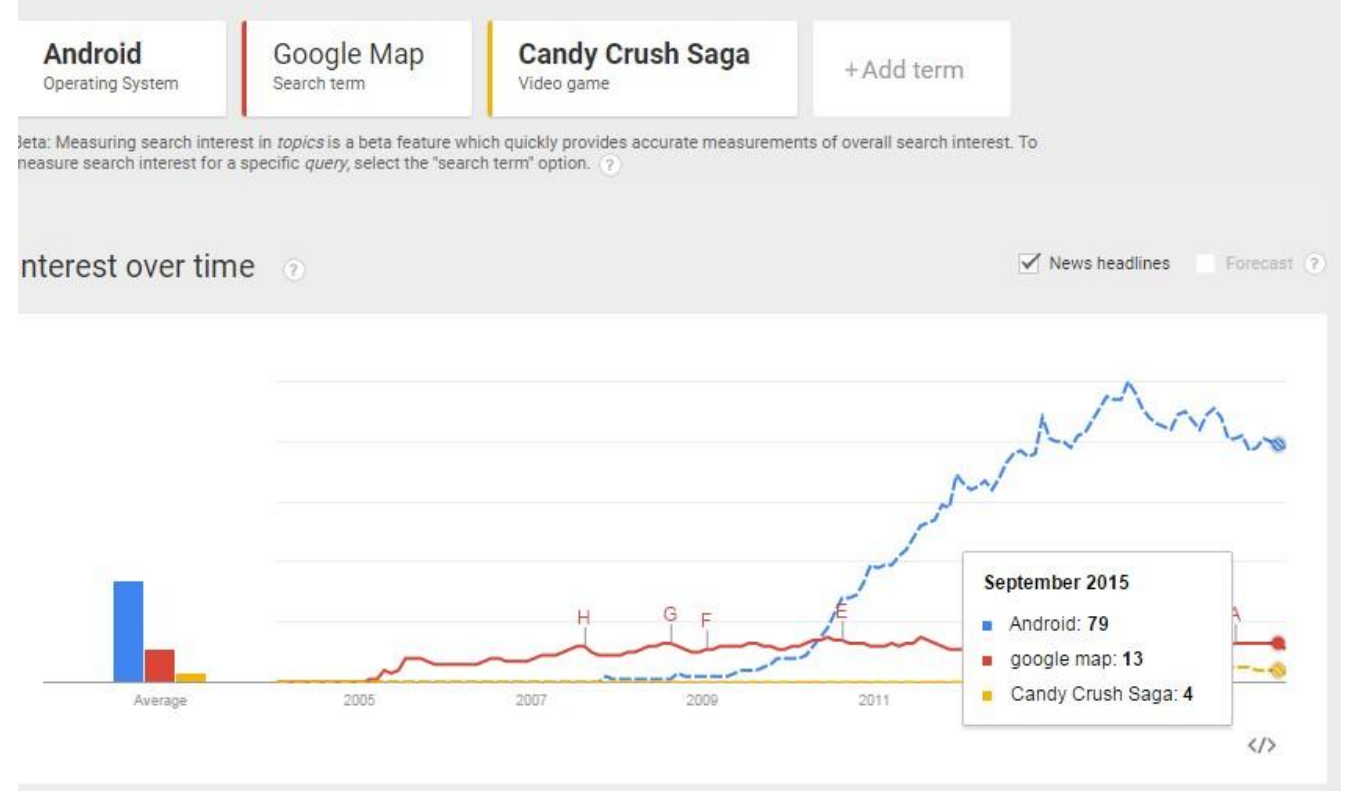

Fig 3 Comparison of Growth of various Mobile Computing platforms in past years 
Table 3: Summary on SMAC on the basis of various company report and studies on SMAC

\begin{tabular}{|c|c|c|c|c|}
\hline $\begin{array}{c}\text { S.No } \\
\text {. }\end{array}$ & Title & $\begin{array}{c}\text { Company/Pub } \\
\text { lisher }\end{array}$ & Approach & Summary \\
\hline 1 & $\begin{array}{l}\text { Building SMAC } \\
\text { strategies for a } \\
\text { new futuristic } \\
\text { foundation }\end{array}$ & AVASANT & $\begin{array}{lr}\text { A 3I } & \text { (Integrated } \\
\text { Insightful } & \text { Innovative } \\
\text { )Framework } & \text { for } \\
\text { developing } & \text { SMAC } \\
\text { technology } & \end{array}$ & $\begin{array}{l}\text { Traditional technologies were isolated In } \\
\text { nature. SMAC gives an edge over those } \\
\text { technologies because its four components } \\
\text { (Social media ,Mobility, Analytics, Cloud } \\
\text { )inevitably complement each other and increase } \\
\text { overall effectiveness of the technology }\end{array}$ \\
\hline 2 & $\begin{array}{l}\text { Accelerate your } \\
\text { transformation : } \\
\text { Social } \\
\text {, Mobile and } \\
\text { analytics in cloud }\end{array}$ & CAPGEMINI & $\begin{array}{l}\text { Implementation of SMAC } \\
\text { stacks with help of } \\
\text { GOOGLE APPS in order to } \\
\text { personify the vision of a } \\
\text { digital transformation of } \\
\text { the enterprise. }\end{array}$ & $\begin{array}{l}\text { SMAC works in a direction of innovation and } \\
\text { allows an enterprise to explore ways for } \\
\text { organization's workplace satisfaction, research } \\
\text { and product development. }\end{array}$ \\
\hline 3 & $\begin{array}{l}\text { The SMAC effect } \\
\text { towards adaptive } \\
\text { supply chain } \\
\text { management }\end{array}$ & $\begin{array}{l}\text { CSI } \\
\text { communication } \\
\text { May'2014 } \\
\text { edition }\end{array}$ & $\begin{array}{c}\text { Implementation of SMAC } \\
\text { stack to form an } \\
\text { E-enterprises }\end{array}$ & $\begin{array}{l}\text { The four cutting edge ameliorate SCM in a } \\
\text { manner to make it more adaptive and } \\
\text { improve its features. }\end{array}$ \\
\hline 4 & $\begin{array}{l}\text { Don't get Smacked: } \\
\text { How SMAC } \\
\text { technologies are } \\
\text { reshaping an } \\
\text { enterprise }\end{array}$ & $\begin{array}{c}\text { COGNIZAN } \\
\mathrm{T}\end{array}$ & $\begin{array}{l}\text { Business model that brings } \\
\text { SMAC stack as fifth wave } \\
\text { in corporate IT and } \\
\text { implement key knowledge } \\
\text { process }\end{array}$ & $\begin{array}{l}\text { The paper firmly defines that emerging } \\
\text { organization has an advantage of key } \\
\text { knowledge process and implement SMAC stack } \\
\text { for economic growth. }\end{array}$ \\
\hline 5 & $\begin{array}{l}\text { SMAC : The } \\
\text { next growth } \\
\text { driver for } \\
\text { SMEs in India }\end{array}$ & $\begin{array}{l}\text { ASSOCHAM } \\
\text { India EY }\end{array}$ & $\begin{array}{l}\text { SMEs grasping } \\
\text { SMAC technology } \\
\text { vanquishing } \\
\text { economic barrier }\end{array}$ & $\begin{array}{l}\text { The affordable and adaptive feature of SMAC } \\
\text { technologies is opening up grounds for almost } \\
\text { all sized business enterprise including SMEs. }\end{array}$ \\
\hline 6 & $\begin{array}{l}\text { The SMAC code : } \\
\text { Embracing new } \\
\text { tech. for future } \\
\text { businessmen }\end{array}$ & KPMG \& CII & $\begin{array}{l}\text { New opportunity for } \\
\text { Indian IT- BPO sectors } \\
\text { due to emergence of } \\
\text { SMAC technology. }\end{array}$ & $\begin{array}{c}\text { The four forces working collectively under } \\
\text { SMAC technology improves agility of any } \\
\text { enterprise and proves to be a leveraging } \\
\text { opportunity. }\end{array}$ \\
\hline
\end{tabular}

\subsection{Search Strategy}

For searching research papers, we used Google search engine and MSN search engine. For this activity, we made some combinations from the area of SMAC. Some of those combinations are as follows-

- SMAC Technologies

- SMAC in business

- Growth of SMAC

- SMAC with other technologies

- $\quad$ SMAC Benefits

- Relationship between Social and Cloud computing

- Mobile computing and its growth
- Analytics in Corporate world

\section{GROWTH OF SMAC PLATFORMS}

Our In the following section growth of SMAC is depicted by figures. The following figures are generated from google trends. Figure 1 shows the growth of SMAC techniques individual. Figure 2 Comparison of Growth of various Social networking platforms in past years.

Figure 3 Comparison of Growth of various mobile platforms in past years and fig 4 Comparison of Growth of various cloud computing platforms in past years. Figure 5 shows Comparison of Growth of various data analysis platforms in past years. Table 3 gives one statement summary about SMAC in context to various companies' perspective. 


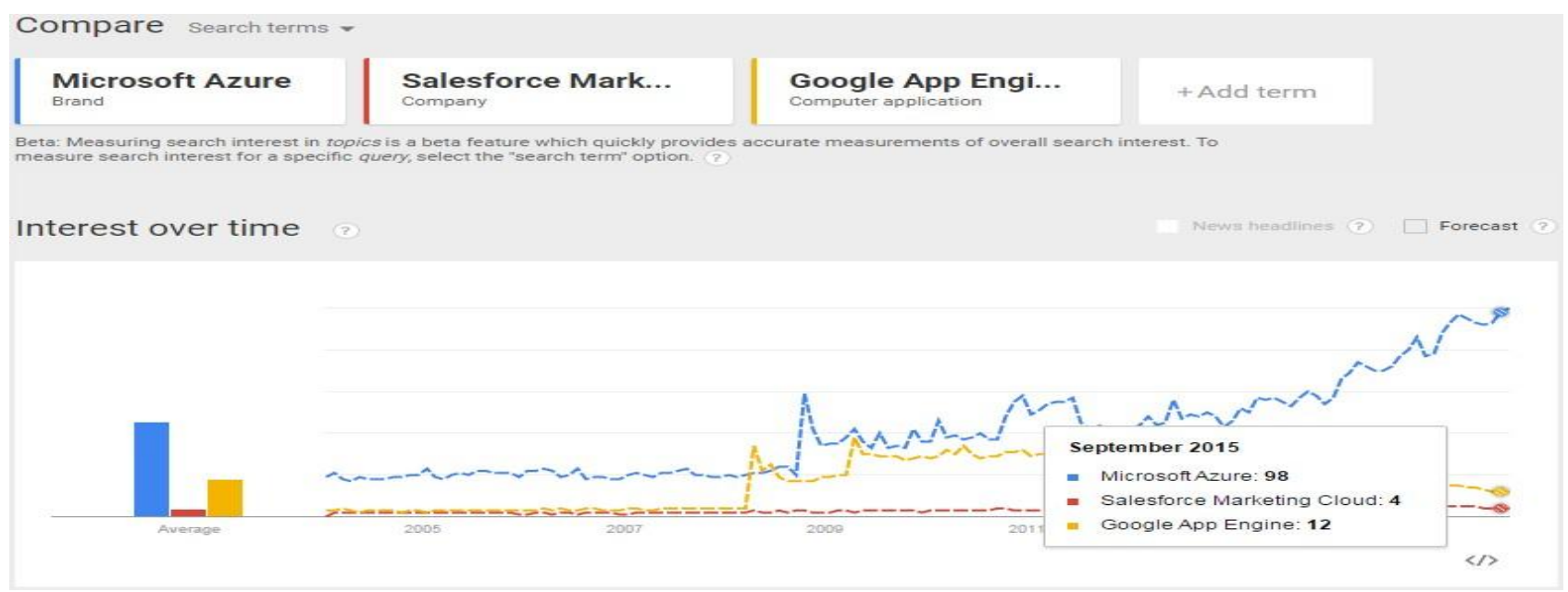

Fig 4 Comparison of Growth of various cloud computing platforms in past years

Compare searchterms -
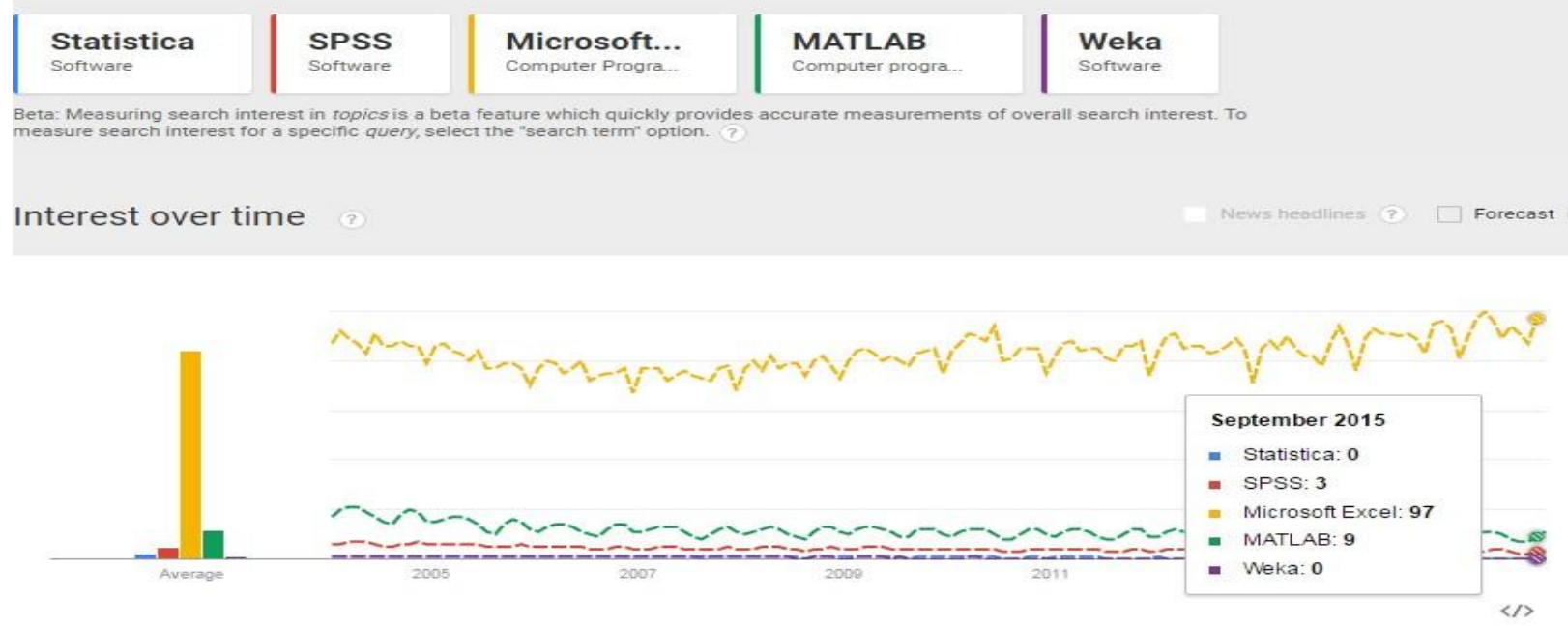

Fig 5 Comparison of Growth of various analytics platforms in past years

\section{CONCLUSION}

This study gives the review on the growth of the SMAC computing. SMAC has been evolved so much in past time and shows its role almost in every field like education, medical, engineering etc. As considered as the "fifth wave in IT architecture", SMAC Stack is expected to bring transformable change in the structure of handling voluminous data and huge social connectivity. It is evident from the reports and review by various companies, that we have studied, that implementation of SMAC is being welcomed and businesses are looking towards this technology as digital change that is incorporating organization-customer interaction, handling data at best and helping employees to be flexible with their work place.

\section{REFERENCES}

[1] Bowman, M., Debray, S. K., and Peterson, L. L. 1993. Reasoning about naming systems. .

[2] Ding, W. and Marchionini, G. 1997 A Study on Video Browsing Strategies. Technical Report. University of Maryland at College Park.

[3] Fröhlich, B. and Plate, J. 2000. The cubic mouse: a new device for three-dimensional input. In Proceedings of the
SIGCHI Conference on Human Factors in Computing Systems

[4] Tavel, P. 2007 Modeling and Simulation Design. AK Peters Ltd.

[5] Sannella, M. J. 1994 Constraint Satisfaction and Debugging for Interactive User Interfaces. Doctoral Thesis. UMI Order Number: UMI Order No. GAX9509398., University of Washington.

[6] Forman, G. 2003. An extensive empirical study of feature selection metrics for text classification. J. Mach. Learn. Res. 3 (Mar. 2003), 1289-1305.

[7] Brown, L. D., Hua, H., and Gao, C. 2003. A widget framework for augmented interaction in SCAPE.

[8] Y.T. Yu, M.F. Lau, "A comparison of MC/DC, MUMCUT and several other coverage criteria for logical decisions", Journal of Systems and Software, 2005, in press.

[9] Spector, A. Z. 1989. Achieving application requirements. In Distributed Systems, S. Mullender 